\title{
ANALISIS STABILITAS HARGA BERAS DI KOTA KUPANG
}

\author{
Melgiana Medahil dan Chris N. Namah'1) \\ 1) Jurusan Manajemen Pertanian Lahan Kering \\ Politeknik Pertanian Negeri Kupang \\ J. Prof. Dr. Herman Yohanes Lasiana Kupang P.O.Box. 1152, Kupang 85011 \\ Korespondensi: melgianamedah@yahoo.com
}

\begin{abstract}
Trade Act No. 7 of 2014 article 26 paragraph 3 mandates that" in guaranteeing the supply and stabilization of prices of staple goods and essential goods, the Minister established pricing policies, stock management and logistics as well as export and import management". Rice food supply circulating in Kupang city 75\% comes from Java and Sulawesi, 25\% is local rice (Melgiana and Chris 2018. The amount of rice outside NTT circulating in the market will affect the stability of rice prices in the city of Kupang. This research is a survey activity, data collected sourced from primary and secondary data using descriptive methods. The sampling technique uses a purposive sampling of 92 traders spread across 4 wholesale markets (Oesapa, Oeba, Inpres and Oebobo) the city of Kupang. The results showed that the price of rice in the city of Kupang ahead of the holiday was unstable. Based on the results of a survey in May - September 2019, that the increase in the price of rice during the harvest up to the feast increased by $41.66 \%$ or from the price of $R p .7000$ at the farm level rises to a price of Rp. 12,000 at the end consumer.
\end{abstract}

Keyword : Price stability, rice

\section{PENDAHULUAN}

Beras yang beredar di kota Kupang 75 persen berasal dari Jawa dan Sulawesi, dengan pola distribusi dari pengumpul besar yang ada di lokasi produksi-pedagang besar antar daerah (distributor)—pedagang pengecer (toko)— pengecer II (kios)-konsumen akhir (Melgiana dan Chris, 2018).

Besarnya pasokan pangan khusus beras yang beredar di kota Kupang berasal dari luar dan panjangnya rantai pemasaran menjadi suatu permasalahan yang perlu dikaji terkait dengan stabilitas harga pangan khusus beras di kota Kupang pada musim panen dan paceklik.

Komoditas pangan yang sangat penting bagi bangsa Indonesia adalah beras. Hal ini dikarenakan beras merupakan bahan pangan pokok sebagian besar masyarakat Indonesia dan berperan sebagai komoditas ekonomi. Implikasi ekonominya adalah ketika terjadi peningkatan pendapatan, maka akan diikuti oleh meningkatnya permintaan kuantitas dan kualitas beras yang lebih baik (Arifin et.al, 2004). 
Berbagai regulasi ditetapkan untuk mengatur dan menjaga stabilitas pasokan dan harga pangan. Pemerintah berkepentingan menetapkan regulasi untuk menciptakan tata niaga beras yang berkeadilan melalui penerbitan Peraturan Menteri Perdagangan (Permendag) Nomor 57 Tahun 2017 tentang Penetapan Harga Eceran Tertinggi Beras serta penerbitan Peraturan Menteri Pertanian (Permentan) Nomor 31 Tahun 2017 tentang Kelas Mutu Beras. Pengaturan Harga Eceran Tertinggi (HET) untuk komoditas beras di dalam Permendag 57 Tahun 2017 telah mempertimbangkan struktur biaya yang wajar dalam hal biaya produksi, distribusi, keuntungan seluruh pelaku serta biaya lainnya. Besaran HET yang telah ditentukan harus menjadi acuan seluruh pelaku usaha dalam pemasaran beras di tingkat eceran. Dalam peraturan ini, pelaku usaha wajib mencantumkan: (a) Label Medium/Premium pada kemasan; (b) Label Harga Harga Eceran Tertinggi pada kemasan; (c) Ketentuan Harga Eceran Tertinggi dikecual ikan terhadap Beras Medium dan Beras Premium yang ditetapkan sebagai Beras Khusus oleh Menteri Pertanian.

Permendag Nomor 57 Tahun 2017 juga mengatur sanksi bagi pelaku usaha yang menjual harga beras melebihi Harga Eceran Tertinggi dikenai sanksi pencabutan izin usaha oleh pejabat penerbit, setelah diberikan peringatan tertulis oleh pejabat penerbit. Harga Eceran Tertinggi (HET) Diseluruh Indonesia Ketentuan besaran HET beras per wilayah adalah: (a) Jawa, Lampung, Sumsel, Bali, NTB, dan Sulawesi untuk Medium Rp 9.450/Kg dan Premium Rp 12.800/Kg; (b) Sumatera Lainnya dan Kalimantan untuk Medium Rp 9.950/Kg dan Premium Rp 13.300/Kg; (c) NTT untuk Medium Rp 9.500/Kg dan Premium Rp 13.300/Kg; dan (d) Maluku dan Papua untuk Medium Rp 10.250/Kg dan Premium Rp 13.600/Kg. Dalam UU tersebut tersirat bahwa pemerintah mempunyai pedoman dalam menetapkan kebijakan harga dengan tujuan untuk stabilisasi harga. Tujuan dari penelitian ini yaitu: mengetahui stabilitas harga beras pada 4 pasar (Oeba, Oebobo, Inpres, Oesapa) di kota Kupang.

\section{METODE PENELITIAN}

Penelitian dilaksanakan pada bulan April - Oktober 2019 pada 4 pasar (di kota Kupang. Metode yang digunakan pada penelitian ini yaitu metode deskriptif dengan jenis penelitian deskriptif, dan teknik penarikan sampel yang digunakan adalah purpose sampling dengan jumlah sampel sebanyak 92 orang 
pedagang di kota Kupang yang tersebar di 4 pasar induk (Oesapa, Oeba, Inpres dan Oebobo) kota Kupang.

Untuk menjawab tujuan tersebut menggunakan analisis deskriptif dengan data patokan harga yang ditetapkan pemerintah dan harga yang berlaku di pasar di kota Kupang.

\section{HASIL DAN PEMBAHASAN}

\section{Umur Responden}

Umur sangat menentukan kemajuan yang telah dicapai oleh seorang pedagang, sehingga umur merupakan salah satu faktor penting bagi pedagang dalam mengelolah usaha dagangannya ke arah yang lebih baik. Selain itu umur para pelaku usaha dagang turut menentukan sikapnya dalam pengambilan keputusan, termasuk dalam hal mengadopsi teknologi baru.

Pedagang yang berusia lanjut yang kemampuan fisiknya sudah menurun dan mengalami kesulitan dalam menerima perubahan dan inovasi baru dikarena selalu berpijak pada pengalaman masa lalunya. Berbeda halnya pada pedagang yang usia masih muda, disamping kemampuan fisiknya masih kuat, juga lebih kreatif sehingga lebih mudah dalam menerima inovasi baru dan cara- cara baru untuk mengembangkan usaha dagangnya.

Pedagang di kota Kupang rata-rata berada pada usia masih produktif yakni usia 20 - 30 tahun sebanyak 15 jiwa (16.30\%), 31-40 tahun sebanyak 25 jiwa (27.17\%), usia 41-50 tahun sebanyak 37 jiwa (40.21\%), usia 51-60 tahun sebanyak 11 jiwa ( $11.95 \%)$, usia $>60$ sebanyak 4 orang $(4.34 \%)$.

Dilihat dari data diatas dapat dikatakan bahwa responden yang ada di pasar-pasar di kota Kupang berada pada usia produktif. Hal ini sesuai dengan pendapat Surayati (2006), bahwa umur 25- 45 tahun seseorang menentukan prestasi kerja dan kinerja orang tersebut.

\section{Lama Berwirausaha}

Pengalaman memunculkan potensi seseorang. Potensi penuh akan muncul bertahap seiring berjalannya waktu sebagai tanggapan terhadap bermacammacam pengalaman. (Elaine B.Johnson,2007).

Berdasarkan hasil penelitian tingkat pengalaman responden dalam mengelola usaha dagangannya, diperoleh bahwa pengalaman responden yang paling banyak yaitu 20-25 tahun dengan jumlah responden 45 orang (48.91\%), 30 
- 35 tahun dengan jumlah responden 30 orang (32.60\%), 5 - 15 tahun sebanyak 17 orang (18.47\%). Responden memiliki pengalaman wirausaha dalam bidang tataniaga usaha (perdagangan). Pengalaman berusaha seseorang dapat dikatakan cukup berpengalaman apabila menggeluti bidang pekerjaannya selam 5-10 tahun, dengan kata lain 10 tahun keatas dikategorikan sangat berpengalaman, sedangkan 5 tahun ke bawah kurang berpengalaman (Suharjo dan Patong, 2006).

\section{Stabilitas Harga beras di kota Kupang}

Analisis margin pemasaran dilakukan untuk mengetahui perbedaan harga persatuan ditingkat produsen atau ditingkat konsumen yang terjadi pada rantai pemasaran (Sudiyono 2004).

\section{Margin Pemasaran beras di tingkat produsen}

Berdasarkan hasil penelitian di 4 pasar di kota Kupang (pasar Oesapa, Inpres, Oeba, Oebobo), bahwa margin pemasaran pada bulan Mei-Juni 2019 diperoleh dengan tingkat rata-rata Rp. 2000,- per kilogram. Dimana pembelian pada tingkat petani sebesar Rp.7.000,- dan ditingkat pedagang pengecer sebesar Rp.9.000,-. sedangkan pada bulan Juli-Desember 2019 margin pemasaran diperoleh rata-rata Rp.3000,-. Pembelian ditingkat distributor sebesar Rp.10.500,dan ditingkat pedagang pengecer sebesar Rp. 12.000,-

\section{Stabilitas Harga Harga Beras di Kota Kupang.}

Permendag Nomor 57 Tahun 2017 yang mengatur tentang Ketentuan besaran harga eceran tertinggi (HET) beras per wilayah adalah: (a) Jawa, Lampung, Sumsel, Bali, NTB, dan Sulawesi untuk Medium Rp 9.450/Kg dan Premium Rp 12.800/Kg; (b) Sumatera lainnya dan Kalimantan untuk Medium Rp 9.950/Kg dan Premium Rp 13.300/Kg; (c) NTT untuk Medium Rp 9.500/Kg dan Premium Rp 13.300/Kg; dan (d) Maluku dan Papua untuk Medium Rp 10.250/Kg dan Premium Rp 13.600/Kg

Tabel 1. Presentasi perbandingan antara harga jual eceran di pasar dan harga yang ditetapkan pemerintah

\begin{tabular}{llcccc}
\hline No & $\begin{array}{l}\text { Nama } \\
\text { Pasar }\end{array}$ & $\begin{array}{c}\text { Nama } \\
\text { Komoditi }\end{array}$ & $\begin{array}{c}\text { Rata -Rata Harga } \\
\text { Pasar (Rp) }\end{array}$ & $\begin{array}{c}\text { Harga } \\
\text { Pemerintah } \\
\text { (Rp). }\end{array}$ & $\begin{array}{c}\text { Presentasi } \\
\text { (\%) }\end{array}$ \\
\hline 1. & Oesapa & Beras & 10.000 & 13.300 & 75.19 \\
2. & Inpres & Beras & 10.538 & 13.300 & 79.23 \\
3. & Oebobo & Beras & 10.000 & 13.300 & 75.19 \\
4. & Oeba & Beras & 9.935 & 13.300 & 74.70 \\
\hline & Kota & & $10.118,25$ & 13.300 & 76.07 \\
\hline
\end{tabular}


Jika dilihat kedua penjelasan diatas, jelas terlihat perbedaan antara Permendag Nomor 57 tahun 2017 dan data survei tahun 2019. Berdasarkan hasil survei dan diskusi dengan petani produsen serta lembaga pemasaran di kota Kupang, bahwa harga beras di kota Kupang pada bulan Juli-Desember tidak stabil di pasar. Harga ditentukan oleh distributor harga ini akan masuk sampai bulan April 2020. Harga beras saat panen bulan Mei pada tingkat petani adalah Rp.7000-8000/kg dan setelah musim panen bulan Juli harga beras lokal mencapai $10.500 / \mathrm{kg}$ sedangkan harga beras non lokal berkisar Rp. 11.000$12.000 / \mathrm{kg}$. Harga beras yang berlaku dipasar ditetapkan sesuai musim panen padi. Harga beras rendah pada bulan Mei-Juni dan bulan Juli sampai kembali saat panen harga akan melonjak tinggi.

Hal ini sependapat dengan Suryana dan Hermanto, 2004, bahwa Kebijakan perberasan nasional pada intinya mencakup lima instrumen kebijakan yaitu peningkatan produksi, diversifikasi usaha, kebijakan harga, kebijakan impor, dan distribusi beras untuk keluarga miskin.

Lembaga pemasaran khusus perberasan berdasarkan hasil survei bulan Mei-September 2019, bahwa pelaku usaha belum mengetahui Permendag Nomor 57 Tahun 2017 yang mengatur tentang Ketentuan besaran harga eceran tertinggi (HET) beras per wilayah.

\section{KESIMPULAN}

Berdasarkan hasil penelitian, dapat diambil kesimpulan bahwa stabilitas harga pangan dipengaruhi oleh musim panen dan hari raya besar umat beragama. Harga beras yang berlau dipasar berdasarkan hasil survei dan diskusi dengan petani produsen serta lembaga pemasaran bahwa mereka tidak mengetahui adanya Permendag Nomor 57 Tahun 2017 yang mengatur tentang harga eceran tertinggi beras, sehingga terdapat perbedaan harga antara pemerintah dan harga pasar yang berlaku. Harga beras saat panen bulan Mei pada tingkat petani adalah Rp.7000-8000/kg dan setelah musim panen bulan Juli harga beras lokal mencapai $10.000 / \mathrm{kg}$ sedangkan harga beras non lokal berkisar Rp. 11.000$12.000 / \mathrm{kg}$.

\section{DAFTAR PUSTAKA}

Arifin, B. 2004. Analisis Ekonomi Pertanian Indonesia. Penerbit Buku Kompas, Jakarta 
Data BPS. Komoditas Pangan di NTT, 2017

Elaine B. Johnson; Januari 2007, Contextual teaching \& learning, Cetakan III, Maret2007 Diterbitkan oleh Penerbit MLC Jin.

Melgiana dan Chris, 2018. Pola Distribusi dan Stabilitas harga pangan di kota Kupang. Jurnal Partner Politani Kupang, 2018.

Peraturan Menteri Perdagangan (Permendag) Nomor 27 Tahun 2017 tentang Penetapan harga acuan pembelian beras ditingkat petani

Philip Kotler. 2009. Manajemen Pemasaran jilid 1. Penerbit Erlangga

Ruslan, 2018. Metode Penelitian Public. Penerbit ISBN

Sudiyono, 2004. Pemasaran Pertanian. UMM Press, Malang

Suryana, A. dan Hermanto. 2004. Kebijakan ekonomi perberasan nasional. hlm. 53-72. Dalam F. Kasryno, E. Pasandaran, dan A.M.Fagi (Ed.). Ekonomi Padi dan Beras Indonesia. Badan Penelitian dan Pengembangan Pertanian, Jakarta

Swastha, Basu. 1999. Saluran Pemasaran Konsep dan Strategi Analisis Kuantitatif. BPFE-Yogyakarta, Yogyakarta.

Yunan Syarillah, 2013. Ketahanan Pangan dan Pola distribusi beras di Propinsi Jawa Timur Penerbit : JEJAK : Journal of Economics and Policy,6. 103213. Tahun 2013. 